\title{
LAHIRNYA HAK KEBENDAAN
}

\author{
Trisadini Prasastinah Usanti \\ Fakultas Hukum Universitas Airlangga Surabaya \\ e-mail:aditris@ymail.com
}

\begin{abstract}
ABSTRAK
Hak kebendaan ialah hak mutlak atas suatu benda, dan merupakan hak perdata. Hak ini memberikan kekuasaan langsung atas suatu benda dan dapat dipertahankan terhadap siapa pun juga. Hak kebendaan mempunyai sifat-sifat tertentu dan ciri-ciri unggulan bila dibandingkan dengan hak perorangan. Perbedaan antara hak kebendaan dan hak perorangan terlihat sangat jelas. Hak kebendaan dalam Burgerlijk Wetboek dapat dibedakan menjadi dua, yaitu hak kebendaan yang sifatnya memberikan jaminan (zakelijk zakenheidsrecht) antara lain gadai, hipotek, hak tanggungan, fidusia, dan hak kebendaan yang sifatnya memberikan kenikmatan (zakelijk genotrecht) antara lain bezit dan hak milik. Lahirnya hak kebendaan yang bersifat memberikan kenikmatan ada bermacam-macam cara perolehannya, bergantung pada macam atau jenis bendanya. Sedangkan lahirnya hak kebendaan pada hak kebendaan yang sifatnya memberikan jaminan, bergantung kepada asas publisitas, yaitu dengan cara mendaftarkan ke Kantor Pendaftaran. Sedangkan lahirnya hak kebendaan pada lembaga jaminan gadai tidak ada ketentuan tentang pendaftaran dan hak kebendaan pada lembaga jaminan gadai lahir pada saat benda diserahkan kepada pihak ketiga.
\end{abstract}

Kata kunci: benda, hak kebendaan, publisitas.

\begin{abstract}
Property rights is a right based on private law, and is an absolute right over a thing. Property rights gives direct control over an object and can be defended against anyone. Property rights has it own superior characteristics. There are major differences between property rights and individual rights, because property rights has a superior differences compared with individual rights. Based on Burgerlijk Wetboek property rights divided into two kind, first is property rights which it's character is giving a guarantee (zakelijk zakenheidsrevht) such as pawn, fiducia or mortgage, and it born based on publicity principle which is done by registering to the registration office, pawn is an exception, it has no provision about publicity because the rights born when the property has been transfered. The second one is property rights which it's character is giving a pleasure, such as bezit and ownership, this kind of property rights born based on the property type and kind.
\end{abstract}

Keywords: object, property rights, publicity.

\section{PENDAHULUAN}

Di dalam Burgerlijk Wetboek (yang selanjutnya disebut BW) ada dua istilah, yaitu benda (zaak) dan barang (goed) (Mariam Darus Badrulzaman, 2010: 35). Pengertian yang paling luas dari istilah zaak ialah segala sesuatu yang dapat dihaki oleh orang. Disini benda berarti objek sebagai lawan dari subjek atau orang dalam hukum. Ada perkataan benda itu dipakai dalam artian sempit, yaitu sebagai barang yang terlihat saja, juga dipakai dengan maksud kekayaan seseorang. Jika perkataan benda dipakai dalam arti kekayaan seseorang maka perkataan itu meliputi barang-barang yang tak terlihat yaitu hak, misalnya hak piutang atau penagihan (Sri Soedewi M.S., 1981:14).
Pengertian tentang benda diatur pada Pasal 499 BW bahwa yang dinamakan kebendaan ialah tiaptiap barang dan tiap-tiap hak yang dapat dikuasai oleh hak milik. Pengertian ini adalah abstrak, yang dinamakan dengan istilah subjek hukum (pendukung dan kewajiban). Kata dapat mempunyai arti yang penting, karena membuka berbagai kemungkinan, yaitu pada saat-saat yang tertentu sesuatu itu belum berstatus sebagai objek hukum, namun pada saat-saat yang lain merupakan objek hukum seperti aliran listrik (Mariam Darus Badrulzaman, 2010:35). Dalam BW memakai istilah zaak dipakai dalam dua arti, yaitu pertama dalam arti barang yang berwujud, yang kedua dalam arti bagian dari harta kekayaan. 
Merujuk pada ketentuan Pasal 499 BW maka pengertian zaak (benda) dalam perspektif BW tidak saja benda berwujud barang (goed), namun juga termasuk pula di dalamnya pengertian benda yang tidak berwujud yang berupa hak-hak tertentu dari seseorang. Ini berarti objek dari suatu benda bisa saja hak milik (kepemilikan) intelektual atau hak atas kekayaan intelektual sebagai terjemahan dari Intellectual Property Right (Rachmadi Usman, 2011: 59). Pembagian benda dalam $B W$ relatif lebih banyak dan cukup rinci bila dibandingkan dengan pembagian benda menurut hukum adat yang cukup sederhana, yaitu benda berupa tanah dan benda bukan tanah. Secara garis besar jenis-jenis benda yang dikenal BW adalah sebagai berikut (Trisadini P. Usanti, et.al., 2012: 40): a. Benda berujud dan benda tak berujud (lihat Pasal 503 BW); dan b. Benda bergerak dibedakan atas benda bergerak karena sifatnya menurut Pasal 509 BW, yang kedua benda bergerak karena ketentuan undang-undang menurut Pasal 511 BW, dan benda tidak bergerak dibedakan atas tak bergerak menurut sifatnya dan tak bergerak karena tujuannya ialah segala apa yang meskipun tidak secara sungguhsungguh digabungkan dengan tanah atau bangunan dimaksudkan untuk mengikuti tanah atau bangunan itu untuk waktu yang agak lama, yaitu misalnya mesin-mesin dalam suatu pabrik, selanjutnya ialah tak bergerak karena memang demikian, diatur dalam Pasal 507 BW, dan tak bergerak menurut ketentuan undang-undang Ini berwujud hak-hak atas benda yang tak bergerak, misal: hak memungut hasil atas benda tak bergerak, hak memakai atas benda tak bergerak, hipotik dan lain-lain. c. Benda habis pakai dan Benda tidak habis pakai terdapat dalam Pasal 505 BW

Di samping pembedaan benda menurut Pasal 503, 504 dan 505 di dalam BW ada pembedaan macammacam benda, yaitu (Trisadini P. Usanti, et.al., 2012: 40): a. Benda dalam perdagangan dan benda di luar perdagangan (lihat Pasal $1332 \mathrm{BW}$ ); b. Benda yang sudah ada dan benda yang masih akan ada dibagi bersifat relatif dan bersifat mutlak (Lihat Pasal 1334 BW); c. Benda yang dapat dibagi dan benda yang tidak dapat dibagi (lihat Pasal 1694 BW), dan; d. Benda yang dapat diganti dan benda yang tidak dapat diganti (lihat Pasal 1163 BW).

Dari pembagian akan macam-macam benda yang dikenal dalam BW, Pembagian benda yang penting dan menonjol adalah pembagian benda bergerak dan benda tidak bergerak, karena pembagian ini membawa akibat hukum yang berbeda, antara lain dalam pembebanan jaminan atau Bezwaring. Dalam BW sudah cukup rinci tentang macam pembagian jenis benda, namun kenyataannya dalam perkembangan adanya kebutuhan untuk menambah pembagian jenis benda yang baru selain yang sudah kenal dalam BW yakni benda terdaftar dan benda tidak terdaftar.

Dimaksud dengan benda terdaftar adalah bendabenda yang didaftar dalam suatu register umum yang dikelola oleh suatu instansi yang diberi wewenang untuk itu. Benda tidak terdaftar adalah benda-benda yang tidak terdaftar di dalam suatu register umum (Moch. Isnaeni, 1996:19). Untuk benda terdaftar cenderung mengikuti alur aturan main benda tidak bergerak. Arti penting pembedaan benda terdaftar dan benda tidak terdaftar terletak pada pembuktian kepemilikannya. Benda terdaftar dibuktikan dengan bukti pendaftarannya, umumnya berupa sertifikat atau dokumen atas nama pemilik, seperti tanah, kendaraan bermotor, hak cipta dan sebagainya. Pemerintah lebih mudah melakukan kontrol atas benda terdaftar, baik dari segi tertib administrasi kepemilikan maupun dari pembayaran pajaknya. Benda tidak terdaftar sulit untuk mengetahui dengan pasti siapa pemilik yang sah atas benda itu, karena berlaku asas 'siapa yang menguasai benda itu dianggap sebagai pemiliknya'. Contohnya: perhiasan, alat alat rumah tangga, benda elektronik, pakaian dan sebagainya (Modul Hukum Benda, 2009:5).

Hak kebendaan zakelijk recht ialah hak mutlak atas suatu benda, hak itu memberikan kekuasaan langsung atas suatu benda dan dapat dipertahankan terhadap siapa pun juga. Hak kebendaan lawannya adalah hak perseorangan atau persoonlijk recht merupakan bagian dari hukum perdata. Hak kebendaan dalam BW dapat dibedakan: 1 . Hak kebendaan yang memberikan jaminan atau zakelijk zekenheidsrecht contoh: gadai, hipotek, hak tanggung, fidusia; 2. Hak kebendaan yang memberikan kenikmatan atau zakelijk genotsrecht contoh: hak milik, bezit.

Berdasarkan dari uraian di atas, maka permasalahan yang dikaji yaitu bilamana lahirnya hak kebendaan sehingga ciri-ciri hak kebendaan tersebut melekat pada benda tersebut.

\section{PEMBAHASAN}

Hak kebendaan adalah hak mutlak yang dilawankan dengan hak yang nisbi, keduanya adalah bagian dari hak perdata. Hak perdata dirinci menjadi dua, yaitu (Sri Soedewi M.S.,1981:24): Pertama, Hak mutlak atau hak absolut terdiri atas: a. Hak kepribadian, misalnya hak atas namanya, hidup, kemerdekaan; b. Hak yang timbul dalam hukum keluarga, yaitu hak yang timbul karena adanya hubungan antara suami istri, hubungan antara orang dan anak; c. Hak mutlak atas suatu benda, 
ini yang disebut sebagai hak kebendaan. Kedua, Hak nisbi (hak relative atau hak persoonlijk), yaitu semua hak yang timbul karena adanya hubungan perutangan yang hanya dapat dipertahankan untuk sementara orang-orang tertentu saja.

Hak kebendaan mempunyai ciri-ciri unggulan bilamana dibandingkan dengan hak perseorangan. Perbedaan antara hak kebendaan dan hak perseorangan sedemikian tajamnya, hal ini dapat diuraikan sebagai berikut (Trisadini P. Usanti, et.al., 2012:43):

Pertama, Hak kebendaan merupakan hak yang mutlak, yaitu dapat dipertahankan terhadap siapa pun, tidak sekedar pada rekan sekontraknya saja tetapi juga kepada pihak-pihak lain yang mungkin di kemudian hari ikut terkait didalamnya. Hal ini berbeda dengan hak perorangan atau hak relatif yang hanya bisa ditegakkan pada pihak tertentu saja. Sebagai contoh: dalam perjanjian sewa menyewa antara $\mathrm{A}$ dan $\mathrm{B}$ maka hak yang lahir adalah hak perorangan, jadi kalau B tidak membayar uang sewa maka $A$ hanya dapat menagih pada lawan kontraknya saja (lihat Pasal 1315 jo. 1340 BW tentang privity of contract). Berbeda dengan pemegang hak kebendaan, seperti hak milik atas suatu benda maka pemiliknya dapat menuntut kemanapun benda itu berada dengan hak yang diberikan oleh undang-undang yaitu Hak Revindikasi (Pasal 574 BW).

Kedua, Hak kebendaan itu mempunyai zaaksgevolg atau droit de suit (hak yang mengikuti), artinya hak itu akan tetap mengikuti bendanya ke tangan siapa pun benda itu berada. Jadi hak kebendaan itu melekat pada bendanya sehingga kalau berpindah tangan yang bersangkutan akan terkena pula untuk wajib menghormatinya. Sebagai contoh: A mempunyai sebidang tanah yang sudah dibebani Hak Tanggungan oleh Bank Eko, Bank Eko mempunyai hak kebendaan atas sebidang tanah tersebut (hak kebendaan yang sifatnya memberi jaminan), apabila A kemudian menyewakan tanah tersebut kepada D maka hak kebendaan (hak tanggungan) yang dimiliki oleh Bank Eko tetap mengikuti bendanya. Contoh untuk hak perorangan, ialah A mempunyai hak pinjam pakai (Pasal 1740 BW) atas rumah milik B. Kemudian B menjual rumah tersebut kepada $\mathrm{C}$, hak yang dimiliki oleh $\mathrm{A}$ adalah hak perseorangan sehingga $\mathrm{A}$ tidak bisa mempertahankan haknya. Hak perseorangan berhenti sejak dijualnya rumah itu kepada $\mathrm{C}$.

Ketiga, Hak kebendaan berlaku asas prioritas, artinya bahwa hak kebendaan yang lahir terlebih dahulu akan diutamakan daripada yang lahir kemudian. Dengan begitu, saat kelahiran hak itu memegang peranan penting, karena yang lahir lebih dahulu akan dibayar paling awal, sedang yang belakangan harus menunggu yang ada di depannya. Misalnya: A memiliki sebidang tanah yang telah dijaminkan pada B sehingga lahir hak tanggungan I, kemudian dijaminkan lagi kepada $\mathrm{C}$ dengan hak tanggungan II, maka hak kebendaan yang dimiliki oleh $\mathrm{B}$ akan diprioritaskan dibandingkan dengan hak kebendaan yang dimiliki oleh C karena hak kebendaan yang dimiliki oleh B lahir terlebih dahulu. Contoh pada hak perorangan: A mempunyai hak pinjam pakai atas rumah milik B, kemudian $\mathrm{B}$ memberikan pinjam pakai pada $\mathrm{C}$, maka hak yang dimilki oleh A dan $\mathrm{C}$ adalah sederajat.

Keempat, Hak kebendaan mempunyai droit de preference (hak terlebih dahulu), adanya preferensi ini diatur dalam Pasal 1133 BW, bahwa pihak yang memiliki hak kebendaan ini dalam hal pelunasan harus lebih didahulukan pembayarannya, seketika kalau benda yang dijadikan obyek hak tersebut laku dalam pelelangan. Misalnya A menjaminkan sebidang tanah kepada $\mathrm{B}$ dengan hak tanggungan, disamping itu A juga berhutang pada $\mathrm{C}$, bilamana $\mathrm{A}$ jatuh pailit maka $\mathrm{B}$ dapat mempertahankan hak kebendaannya, tidak demikian dengan $\mathrm{C}$ yang hanya memegang hak perorangan, tidak didahulukan dalam hal pembayaran hanya berkedudukan sebagai kreditor konkuren (Pasal 1132 BW).

Kelima, Pada hak kebendaan gugatnya disebut gugat kebendaan. Pada hak kebendaan ini orang mempunyai beragam permintaan (actie) jika terdapat gangguan atas haknya misalnya berwujud: penuntutan kembali, gugatan untuk menghilangkan gangguangangguan atas haknya, gugatan untuk pemulihan ke dalam keadaan semula. Sebagaimana hak yang dimiliki seorang pemilik dengan melakukan gugat revindikasi berdasarkan Pasal 574 BW. Sedang pada hak perorangan gugat ini disebut gugat perseorangan. Pada hak perorangan, orang hanya dapat mengajukan gugatan pada pihak lawannya saja.

Asas-asas pembagian dalam hak kebendaan sebagai berikut (Mariam Darus Badrulzaman, 2010:36): 1. Asas sistem tertutup, hak kebendaan mempunyai sistem tertutup. Maksudnya ialah bahwa hak-hak atas benda bersifat limitatif, terbatas hanya pada yang diatur undang-undang. Di luar itu, dengan perjanjian tidak diperkenankan menciptakan hak-hak baru; 2 . Asas hak mengikuti benda (zaaksgevolg, droit de suite), asas ini mengatakan bahwa hak kebendaan mengikuti bendanya dimana saja dan dalam tangan siapa pun benda tersebut berada; 3 . Asas publisitas, yang dimaksud dengan publisitas (openbaarheid) adalah "pengumuman" kepada masyarakat mengenai status pemilikan. Pengumuman hak atas benda tetap 
(tanah) terjadi melalui pendaftaran dalam buku tanah, sedangkan pengumuman benda bergerak melalui penguasaan nyata benda itu; 4 . Asas spesialitas, dalam lembaga hak kepemilikan atas tanah secara individual harus ditunjukkan dengan jelas wujud, batas, letak, luas tanah. Asas ini terdapat pada hak (milik, guna usaha, guna bangunan) atas benda tetap; 5. Asas totalitas, hak kepemilikan hanya dapat diletakkan terhadap objeknya secara totalitas, dengan perkataan lain hak itu tidak dapat diletakkan hanya untuk bagian-bagian benda. Pemilik sebuah bangunan dengan sendirinya adalah pemilik kusen, jendela, pintu dan genteng rumah; 6. Asas accessie, dari asas totalitas ini muncul asas perlekatan (accessie). Suatu benda lazimnya terdiri dari bagian-bagian yang melekat menjadi satu dengan benda pokok, seperti hubungan antara bangunan dengan genteng, kusen, pintu dan jendela; 7. Asas pemisahan horizontal, BW mengenal asas perlekatan vertikal dalam Pasal 571, 600, 601, 603, 604 dan 605 sedangkan Undang-Undang No. 5 Tahun 1960 tentang Undang-Undang Pokok Agraria menganut pemisahan horizontal yang diambil dari asas hukum adat; 8. Asas dapat diserahkan, Hak kepemilikan mengandung wewenang untuk menyerahkan benda; 9. Asas perlindungan, perlindungan bagi pihak yang beritikad baik walaupun yang menyerahkan adalah pihak yang tidak berwenang berhak (beschikkings on bevoegd), sebagaimana diatur pada Pasal 1977 ayat $1 \mathrm{BW} ; 10$. Asas absolut (hukum pemaksa), ketentuan-ketentuan yang mengatur hukum benda bersifat absolut artinya bahwa hak kebendaan wajib dihormati dan ditaati oleh setiap orang.

Menurut Mariam Darus Badrulzaman, lembaga pendaftaran tidak semata-mata mengandung arti untuk memberikan alat bukti yang kuat, akan tetapi juga menciptakan hak kebendaan. Hak kebendaan atas suatu benda (tanah) terjadi pada saat pendaftaran dilakukan. Tanpa sifat kebendaan hak atas tanah belum mempunyai kaitan dengan milik. Dalam arti selama pendaftaran belum dilakukan, hak hanya mempunyai arti terhadap para pihak pribadi, dan umum belum mengetahui perubahan status hukum dari benda. Pengakuan masyarakat baru terjadi pada saat hak milik atas benda tersebut didaftarkan. Dengan pendaftaran lahirlah pengakuan umum atas hubungan hak dengan benda (Mariam Darus Badrulzaman, 2010:37).

Dalam praktik pembedaan hak kebendaan dan hak perorangan menjadi sangat sumir, tidak mutlak. Sifat-sifat pertentangan tidak tajam lagi. Dalam praktik dijumpai hak kebendaan yang mempunyai ciri-ciri yang unggul menjadi melemah dan menampakkan ciri-ciri hak perorangan, hal ini terjadi relativering hak kebendaan, yaitu bilamana dalam kasus tersebut diterapkan Pasal 1977 BW. Demikian juga sebaliknya hak perorangan yang mempunyai sifat relatif menjadi menguat menampakkan sifat-sifat hak kebendaan, hal ini terjadi verzakelijking hak perorangan bilamana dalam kasus tersebut diterapkan Pasal 1365 BW, Pasal 1576 BW, Pasal 1556 BW, dan Pasal 1318 BW.

Relativering Hak Kebendaan dalam contoh: A pemilik sebuah laptop meminjamkan laptop tersebut kepada B, kemudian oleh B laptop itu dijual kepada $\mathrm{C}$ yang mengira bahwa laptop itu milik $\mathrm{B}, \mathrm{C}$ dengan itikad baik membeli dengan harga yang pantas, maka siapakah yang dilindungi A atau C. Hak kebendaan yang dimiliki oleh A yang mempunyai sifat-sifat unggulan, yaitu droit de suite, akan tetapi dalam kasus di atas hak kebendaan yang dimiliki oleh A tidak dapat dipertahankan terhadap hak yang dimiliki oleh C. Eigendom dari benda bergerak meskipun suatu hak kebendaan sebegitu jauh adalah relatif dalam keadaan tertentu kehilangan droit de suit. Adagium "benda bergerak tidak mempunyai droit de suite" adalah suatu ungkapan yang tepat. "Barangsiapa secara sukarela melepaskan benda bergerak, maka ia tidak dapat menuntut hak miliknya yang dikuasai oleh pihak ketiga yang telah memperoleh dengan itikad baik (tegoeder trouw) Pasal 1977 ayat 1 BW" jadi A tidak dapat merevindiceer buku itu dari C (R. Soetojo Prawirohamidjojo dan Marthalena Pohan, 1984:16).

Verzakelijking Hak Perorangan dalam contoh: A menyewakan rumah kepada B, sebelum B memasuki rumah yang disewanya, A menyewakan lagi kepada $\mathrm{C}$, dan $\mathrm{C}$ tahu betul bahwa adanya hubungan sewamenyewa antara $\mathrm{A}$ dengan $\mathrm{B}$, dan $\mathrm{C}$ mendahului untuk memasuki rumah itu. Baik $\mathrm{B}$ dan $\mathrm{C}$ masing-masing mempunyai hak perorangan berdasarkan perjanjian sewa menyewa dengan $\mathrm{A}$. Siapa yang dilindungi $\mathrm{B}$ atau C. Pada asasnya pada hak perorangan tidak dikenal asas prioritas kedudukannya adalah sama. Akan tetapi karena $\mathrm{C}$ melakukan perbuatan onrechtmatig terhadap B, maka B dapat mengajukan gugat atas dasar Pasal 1365 BW untuk menuntut pada hakim supaya $C$ mengosongkan rumah itu untuk kepentingan B (R. Soetojo Prawirohamidjojo dan Marthalena Pohan, 1984:19).

Hak kebendaan yang memberikan kenikmatan atas bendanya milik sendiri yaitu hak milik atas benda bergerak dan benda tidak bergerak. Pada Pasal 584 BW diatur cara memperoleh hak milik:

Hak milik atas sesuatu kebendaan tidak dapat diperoleh dengan cara lain, melainkan dengan cara pemilikan, karena perlekatan, karena daluwarsa, karena pewarisan, baik menurut undang-undang maupun menurut surat wasiat, dan karena 
penunjukan atau penyerahan berdasar atas suatu peristiwa untuk memindahkan hak milik dilakukan oleh seorang yang berhak berbuat bebas terhadap kebendaan itu.

Dalam Pasal 584 BW diatur tentang macammacam cara memperoleh hak milik, akan tetapi cara memperoleh hak milik yang diatur pada Pasal 584 BW ialah secara enuntiatif, artinya pasal 584 BW hanya menyebutkan beberapa cara saja sedangkan di luar Pasal 584 BW masih ada beberapa cara lain untuk memperoleh hak milik.

Salah satu cara memperoleh hak milik yang paling penting dan sering terjadi dalam masyarakat adalah dengan cara penyerahan (levering/overdracht), yang dimaksud dengan levering adalah penyerahan suatu benda oleh pemilik atau atas namanya kepada orang lain, sehingga orang lain memperoleh hak milik atas benda tersebut. Dalam sistem hukum Prancis tidak mengenal levering, misalnya dalam jual-beli, para pihak sepakat melakukan perjanjian jual-beli maka hak milik sudah beralih tidak perlu diikuti dengan adanya levering. Sedangkan di dalam Pasal 1457 BW bahwa jual-beli meliputi dua tahapan, yaitu tahap pertama perjanjian jual-beli hanya bersifat obligatoir yang melahirkan kewajiban saja, yaitu kewajiban menyerahkan benda dan kewajiban untuk membayar harga benda, pada tahap ini tidak berakibat hak milik berpindah. Hak milik berpindah pada tahap kedua, yaitu setelah adanya levering (transfering of ownership). Macam-macam cara penyerahan dari benda itu dibedakan sesuai dengan sifat benda itu, yaitu: 1. Benda bergerak, masih dibedakan: Benda bergerak yang berwujud dan Benda bergerak tidak berwujud; 2. Benda tidak bergerak.

Penyerahan Benda bergerak itu dibedakan atas: Benda bergerak yang berujud (tertuang Pasal 612 ayat $1 \mathrm{BW}$ ) dilakukan dengan penyerahan nyata atau penyerahan dari tangan ke tangan. Akan tetapi ada kalanya penyerahan terhadap benda bergerak berujud tidak perlu dilakukan penyerahan dari tangan ke tangan karena benda yang akan diserahkan itu berada dalam tangan orang yang hendak menerimanya berdasarkan atas hak yang lain (Pasal 612 ayat (2) BW). Ada 2 macam penyerahan, yaitu (Rachmadi Usman, 2011: 209; Sri Soedewi M.S., 1981:69): Pertama, Tradition brevi manu (penyerahan dengan tangan pendek), misalnya A meminjam arloji milik B, kemudian B membutuhkan uang dengan menjual arloji tersebut kepada A, dalam hal ini tidak diperlukan levering karena arloji tersebut sudah ada di tangan A. Kedua, Constitutum possessorium yaitu penyerahan dengan melanjutkan penguasaan atas bendanya, misalnya $\mathrm{A}$ pemilik sebuah sepeda karena membutuhkan uang dijual kepada B, akan tetapi A masih membutuhkan untuk lomba sepeda sehingga sepeda tersebut masih berada dalam kekuasaan A.

Diluar ketentuan Pasal 612 ayat 2 BW penyerahan juga tidak perlu dilakukan dalam hal benda yang dijadikan objek perjanjian berada di tangan pihak ketiga, artinya penyerahan dilakukan melalui pihak ketiga. Tradition longa manu (penyerahan dengan tangan panjang) misalnya A meminjamkan buku kepada B, kemudian oleh A buku tersebut dijual ke $\mathrm{C}$, maka penyerahan ke $\mathrm{C}$ dilakukan oleh $\mathrm{B}$.

Benda bergerak tidak berwujud dapat dibedakan menjadi (Frieda Husni Hasbullah, 2005:129): Pertama, Penyerahan atas piutang aan toonder diatur dalam Pasal 613 ayat 3 BW dilakukan dengan penyerahan nyata misal: uang kertas. Kedua, Penyerahan atas piutang (vordering op naam atau atas nama) diatur di dalam Pasal 613 ayat 1 BW dilakukan dengan cessie, yaitu dengan membuat akte otentik atau akta di bawah tangan. Contoh: Andi meminjamkan uang sebesar Rp600.000,00 kepada Budi yang akan dibayar kembali pada tanggal 19 Juli 2012. Pada tanggal 15 Maret 2012 Andi sangat membutuhkan uang, Andi menjual piutang atas nama (tagihannya kepada Budi) kepada Citra sebesar Rp400.000,00. Citra sekarang sebagai kreditor menggantikan Andi. Kreditor yang memindahkan tagihan, yaitu Andi disebut dengan cedent, sedangkan yang memperoleh tagihan kreditor baru yaitu Citra disebut cessionaries. Ada pergantian kreditor lama kepada kreditor baru. Setelah dibuat akta cessie harus diberi tahu kepada pihak berhutang atau debitor yang disebut cessus. Hal ini menunjukkan bahwa penyerahan barulah mempunyai akibat hukum atau mengikat debitor setelah ada pemberitahuan, atau meskipun tanpa pemberitahuan kepada debitor tetapi jika secara tertulis debitor menyetujui dan mengakui pemindahan tersebut maka ia tetap terikat adanya cessie tersebut (Yahman dan Trisadini P. Usanti, 2011: 241). Pemindahan yang disebut dengan cessie, pada Pasal 613 BW mensyaratkan bahwa persetujuan kebendaan harus dibuatkan akta otentik atau akta di bawah tangan. Penyerahan secara lisan dari suatu tagihan tanpa membawa akibat. Ketiga, Penyerahan atas piutang dengan cara aan order, diatur pada Pasal 613 ayat $3 \mathrm{BW}$ dilakukan dengan penyerahan dari surat itu dan disertasi dengan endossemen (menuliskan di balik surat piutang itu yang menyatakan kepada siapa piutang itu dipindahkan), misal: wesel, cek.

Penyerahan benda tidak bergerak diatur dengan berlakunya Undang-Undang Pokok Agraria (UUPA) dan berdasarkan Peraturan Pemerintah No. 24 Tahun 1997 tentang Pendaftaran Tanah, bahwa penyerahan 
kebendaan tidak bergerak harus dilakukan dengan akta otentik yang dibuat di hadapan PPAT kemudian diumukan dan selanjutnya dengan dibukukan pada register umum. Benda tidak bergerak berupa tanah penyerahannya dilakukan dihadapan PPAT dengan pembuatan akta PPAT dan didaftarkan ke kantor pendaftaran tanah. Dengan demikian berarti bahwa penyerahan kebendaan tidak bergerak selain dilakukan secara nyata juga harus diikuti dengan penyerahan secara yuridis.

Penyerahan (Levering) adalah sah bila memenuhi beberapa syarat, yaitu (Sri Soedewi M.S., 1981: 72): Pertama, Perjanjian kebendaan adalah suatu perjanjian yang mana menyebabkan pindahnya hakhak kebendaan misalnya hak milik, bezit, hipotek, gadai. Dari perjanjian yang zakelijk ini tidak bisa timbul verbintenis, berbeda dengan perjanjian yang terdapat dalam Buku III BW. Perjanjian dalam Buku III itu umumnya bersifat obligatoir perjanjian yang menimbulkan perikatan (verbintenis) yaitu perjanjian yang salah satu pihak harus memberikan prestasi dan yang lain berhak atas prestasi. Perjanjian obligatoir tidak menimbulkan atau menyebabkan pindahnya hak kebendaan, melainkan hanya menimbulkan hak persoonlijk.

Kedua, Alas hak dari pemindahan hak milik. Titel atau alas hak adalah hubungan hukum yang mengakibatkan peralihan benda dalam jual-beli, tukar-menukar. Pasal 583 BW mensyaratkan suatu penyerahan sebagai akibat dari suatu alas hak dari pemindahan eigendom, artinya dalam penyerahan eigendom dianggap adanya suatu kewajiban obligatoir untuk itu. Pengertian alas hak dalam Pasal 584 BW ialah adanya hubungan hukum untuk penyerahan eigendom.

Ketiga, Kewenangan Berhak (beschikkingsbe voegdheid). Dalam Pasal 584 BW mensyaratkan suatu penyerahan sebagai akibat adanya suatu alas hak berpindahnya eigendom yang berasal dari yang berhak atas eigendom-nya. Di samping suatu titel yang sah juga disyaratkan adanya beschikkingsbevoegdheid dari orang yang memindahkan itu sebagai suatu syarat untuk sahnya suatu penyerahan. Syarat ini tidak lain dari pelaksanaan suatu asas hukum yaitu asas nemoplus, bahwa seseorang itu tidak dapat mengalihkan hak melebihi apa yang menjadi haknya. Dan, lazimnya yang wenang untuk menguasai benda itu adalah pemilik. Akan tetapi, Pasal 1977 BW telah menerobos atas syarat kewenangan berhak.

Keempat, Penyerahan nyata (feitelijke levering) dan penyerahan yuridis (juridische levering). Penyerahan nyata, yaitu penyerahan dari tangan ke tangan. Pada benda bergerak penyerahan yuridis dan penyerahan nyata biasanya jatuh bersamaan, sedangkan pada benda tidak bergerak, kedua macam penyerahan tersebut terpisah, penyerahan nyata dengan cara penyerahan kunci rumah sedangkan penyerahan yuridis pada saat terjadi perpindahan hak milik di hadapan Pejabat Pembuat Akta Tanah.

Bezit terhadap benda bergerak berlaku asas yang terdapat dalam Pasal 1977 ayat 1 BW bahwa barang siapa yang menguasai benda bergerak tidak atas nama, dianggap pemilik, ketentuan ini tidak berlaku untuk benda tidak bergerak. Dari Pasal 1977 ayat 1 BW terdapat suatu asas hukum, yaitu bahwa bezit atas kebendaan bergerak berlaku sebagai alas hak (titel) yang sempurna. Demikian juga di dalam Pasal 1977 ayat $1 \mathrm{BW}$ terkandung ketentuan daluwarsa (verjaring) yaitu acquisitieve verjaring dengan tenggang waktu 0 (nol) tahun. Barangsiapa yang membezit kebendaan bergerak dalam hal ini seketika 0 (nol) tahun bebas dari tuntutan pemilik.

Hak kebendaan yang bersifat memberikan jaminan, yaitu Gadai, Hipotek, Hak Tanggungan dan Fidusia. Lahirnya hak kebendaan yang bersifat memberikan jaminan terdapat perbedaan, hal ini digantungkan pada jenis bendanya yang dibebani oleh lembaga jaminan tersebut. Pada jaminan gadai lahirnya hak kebendaan, yaitu pada saat objek gadai diserahkan pada penerima gadai atau pihak ketiga sebagaimana diatur pada Pasal 1152 ayat $1 \mathrm{BW}$.

Berdasarkan ketentuan pada Pasal 1152 ayat 1, maka benda gadai harus diserahkan kepada penerima gadai (kreditor) atau pihak ketiga, sehingga benda tersebut berada dalam kekuasaan penerima gadai (kreditor) atau pihak ketiga. Rasio dari penguasaan ini adalah sebagai perwujudan dari asas publisitas, bahwa hak kebendaan atas benda bergerak itu ada pada penerima gadai atau pihak ketiga. Asas ini disebut asas inbezitstelling, sehingga asas inbezitstelling merupakan perwujudan asas publisitas, membuktikan bahwa perjanjian gadai sebagai perjanjian riil dan sebagai bentuk perlindungan hukum bagi pemegang gadai (kreditor), karena apabila objek dari gadai berupa benda bergerak masih dalam kekuasaan pemiliknya maka tidak menutup kemungkinan adanya itikad buruk dari pemilik benda untuk kemudian mengalihkan bendanya yang sudah dibuat objek jaminan gadai. Sebagaimana diketahui bahwa asas yang berlaku atas benda bergerak, yaitu asas yang terdapat dalam Pasal 1977 ayat 1 BW bahwa "Barangsiapa yang menguasai benda bergerak tidak atas nama dianggap pemilik ....", sehingga pemberi gadai atau pemilik benda berdasarkan asas tersebut dapat leluasa untuk 
mengalihkan bendanya padahal benda tersebut sudah menjadi objek gadai.

Pada lembaga jaminan hipotek, yaitu pada Pasal 1162 BW disebutkan bahwa hipotek adalah suatu hak kebendaan atas benda-benda tidak bergerak untuk mengambil penggantian daripadanya bagi pelunasan suatu perikatan. Lahirnya hipotek bilamana segala ikatan hipotek harus didaftarkan dalam register umum agar setiap orang dapat mengetahuinya sebagaimana diatur pada Pasal 1179 BW: 1. Pendaftaran ikatan hipotek harus dilakukan dalam daftar-daftar umum yang disediakan untuk itu; 2. Dalam hal tidak ada pendaftaran, hipotek itu tidak mempunyai kekuatan apapun, bahkan juga terhadap kreditur yang tidak mempunyai ikatan hipotek.

Suatu ikatan jaminan hipotek mempunyai kekuatan hukum baik terhadap debitor dan kreditor maupun terhadap orang lain pihak ketiga. Hal ini merupakan perwujudan dari asas publisitas di samping itu juga merupakan perlindungan bagi kepentingan kreditor serta kepentingan pihak ketiga. Lahirnya hipotek membawa konsekuensi bahwa kreditor pemegang hipotek berkedudukan sebagai kreditor preferen dan karenanya asas-asas hak kebendaan akan melekat di dalamnya.

Sebagaimana diketahui bahwa objek dari hipotek tidak lagi pada hak atas tanah tetapi terbatas hanya pada objek kapal laut yang berbobot lebih dari 20 $\mathrm{m}^{3}$. Kapal yang telah didaftarkan dalam daftar kapal di Indonesia dapat dijadikan jaminan utang dengan pembebanan hipotek atas kapal. Pembebanan hipotek atas kapal dilakukan dengan pembuatan akta hipotek kapal oleh Pejabat Pendaftar dan Pencatat Baliknama Kapal di tempat kapal didaftarkan dan dicatat dalam daftar induk kapal yang bersangkutan. Sebagai bukti kapal telah dibebani hipotek kepada penerima hipotek diberikan grosse akta hipotek kapal. Grosse akta hipotek kapal mempunyai kekuatan eksekutorial yang sama dengan putusan pengadilan yang telah memperoleh kekuatan hukum yang tetap. Dalam hal penerima hipotek terdiri dari beberapa kreditor yang merupakan sindikasi, pemberian grosse akta hipotek kapal diberikan secara bersamaan dengan grosse akta pendaftaran kapal atau grosse akta baliknama kapal kepada salah satu kreditor anggota sindikasi yang diberi kuasa untuk mewakili sindikasi (Law Librarian's Notes, Hipotek, Pendaftaran, dan Kebangsaan Kapal, http://www.blog.detik).

Berdasarkan pada Pasal 60 Undang-Undang No. 17 Tahun 2008 tentang Pelayaran disebutkan bahwa kapal yang telah didaftarkan dalam Daftar Kapal Indonesia dapat dijadikan jaminan utang dengan pembebanan hipotek atas kapal. Pembebanan hipotek atas kapal dilakukan dengan pembuatan akta hipotek oleh Pejabat Pendaftar dan Pencatat Balik Nama Kapal di tempat kapal didaftarkan dan dicatat dalam Daftar Induk Pendaftaran Kapal. Dokumen yang dibutuhkan untuk lahirnya hak kebendaan atas jaminan hipotek adalah: Pertama, Akta Surat Kuasa Memasang Hipotek. Surat kuasa memasang hipotek merupakan surat kuasa yang dibuat di muka dan atau di hadapan notaris. Surat kuasa ini dibuat antara pemilik kapal dengan orang yang ditunjuk untuk itu. Substansi atau isi surat ini adalah bahwa pemilik kapal memberikan kuasa kepada orang ditunjuk untuk mengurus kepentingannya. Kedua, Grosse Akta Pendaftaran atau Balik Nama. Syarat kapal yang dapat dijadikan jaminan hipotek adalah kapal yang telah didaftarkan pada pejabat yang berwenang. Pejabat yang berwenang untuk mengeluarkan akta pendaftaran kapal laut adalah pejabat pendaftar dan pencatat balik nama. Pejabat yang ditunjuk untuk itu adalah syahbandar, sehingga jelas kapal yang dapat dijadikan jaminan utang dengan pembebanan hipotek atas kapal adalah kapal yang telah didaftarkan di dalam Daftar Kapal Indonesia. Ketiga, Perjanjian Kredit. Perjanjian kredit merupakan perjanjian yang dibuat antara kreditor dengan pemilik kapal (debitor) dan bentuk perjanjiannya tertulis.

Sejak diundangkannya Undang-Undang No. 4 Tahun 1996 tentang Hak Tanggungan atas Tanah Beserta Benda-Benda yang Berkaitan dengan Tanah (selanjutnya disingkat UUHT), maka hak atas tanah bukan merupakan objek dari hipotek tetapi menjadi objek dari hak tanggungan. Hak kebendaan atas jaminan hak tanggungan lahir bilamana dilakukan pendaftaran sebagaimana yang dimaksud di dalam Pasal 13 ayat 5 UUHT (Arie Hutagalung, 2008: 159). Lahirnya hak tanggungan berdasarkan Pasal 13 ayat 5 , yaitu pada hari tanggal buku tanah hak tanggungan sebagaimana dimaksud pada ayat 4 . Tanggal buku tanah hak tanggungan adalah hari ketujuh setelah penerimaan secara lengkap suratsurat yang diperlukan bagi pendaftaran. Lahirnya hak kebendaan atas jaminan hak tanggungan ini digantungkan pada adanya pemenuhan asas publisitas, sehingga bilamana Akta Pemberian Hak Tanggungan (APHT) tidak didaftarkan ke Kantor Pertanahan maka tidak pernah lahir hak kebendaan. Konsekuensinya kreditor tidak berkedudukan sebagai kreditor preferen hanya berkedudukan sebagai kreditor konkuren saja sehingga tidak memiliki ciri-ciri unggulan dari hak kebendaan.

Demikian juga halnya dengan jaminan fidusia, lahirnya fidusia digantungkan pada perwujudan asas 
publisitas sebagaimana diatur pada Pasal 14 ayat 3 Undang-Undang No. 42 Tahun 1999 tentang Jaminan Fidusia (selanjutnya disingkat UUJF) bahwa jaminan fidusia lahir pada tanggal yang sama dengan tanggal dicatatnya jaminan fidusia dalam Buku Daftar Fidusia. Pada praktiknya lembaga pembiayaan konsumen yang memberikan pembiayaan untuk pembelian kendaraan bermotor jarang sekali membuat akta jaminan fidusia secara notariil, akta jaminan fidusia dilakukan dengan pembuatan akta di bawah tangan, hal ini dilakukan untuk kepraktisan dan mengurangi beban biaya bagi konsumen. Sebagaimana diketahui bahwa syarat lahirnya jaminan fidusia, pembebanan benda dengan jaminan fidusia dibuat dengan akta notaris kemudian dilakukan pendaftaran ke Kantor Pendaftaran Fidusia. Akibat hukum tidak adanya pendaftaran maka tidak pernah lahir hak kebendaan dan posisi lembaga pembiayaan konsumen hanya berposisi sebagai kreditor konkuren. Akan tetapi, dalam praktiknya perusahaan pembiayaan konsumen melakukan penyitaan terhadap kendaraan bermotor seakan-akan lahir jaminan fidusia padahal kalau ditinjau dari ketentuan jaminan fidusia perusahaan pembiayaan bukan sebagai kreditor pemegang jaminan fidusia.

Bentuk perjanjian fidusia harus tertulis, hal ini ditegaskan dalam UUJF bahwa bentuk perjanjian fidusia harus tertulis, bahkan harus dibuat dengan akta notaris dalam bahasa Indonesia. Alasan mengapa UUJF menetapkan bentuk khusus (akta notaris) karena dalam Pasal 1870 BW akta notaris merupakan akta otentik yang memiliki kekuatan pembuktian sempurna tentang apa yang dimuat di dalamnya, di antara para pihak beserta ahli warisnya atau pengganti haknya. Mengingat bahwa objek jaminan fidusia pada umumnya adalah barang bergerak yang tidak terdaftar maka sudah sewajarnya bentuk otentik dianggap paling menjamin kepastian hukum (Fred B.G. Tumbuan, 2012:32).

Sejak dikeluarkannya Peraturan Menteri Keuangan RI Nomor 130/PMK.010/2012 tentang Pendaftaran Jaminan Fidusia bagi Perusahaan Pembiayaan yang melakukan pembiayaan konsumen untuk kendaraan bermotor dengan pembebanan jaminan fidusia, maka perusahaan pembiayaan yang melakukan pembiayaan konsumen untuk biaya kendaraan bermotor melalui pembebanan jaminan fidusia, wajib mendaftarkan jaminan fidusia dimaksud pada Kantor Pendaftaran Fidusia. Wajib didaftarnya jaminan fidusia berlaku juga bagi perusahaan pembiayaan yang melakukan pembiayaan untuk kendaraan bermotor konsumen, berdasarkan prinsip syariah dan/atau pembiayaan konsumen kendaraan bermotor yang pembiayaannya berasal dari pembiayaan penerusan (channeling) atau pembiayaan bersama (joint financing). Perusahaan pembiayaan wajib mendaftarkan jaminan fidusia pada Kantor Pendaftaran Fidusia paling lama 30 (tiga puluh) hari kalender terhitung sejak tanggal terjadinya perjanjian pembiayaan konsumen tersebut. Perusahaan pembiayaan dilarang melakukan penarikan benda jaminan fidusia yang berupa kendaraan bermotor apabila Kantor Pendaftaran Fidusia belum menerbitkan sertifikat jaminan fidusia dan menyerahkannya kepada perusahaan pembiayaan. Penarikan benda jaminan fidusia berupa kendaraan bermotor oleh perusahaan pembiayaan wajib memenuhi ketentuan dan juga persyaratan sebagaimana diatur dalam undang-undang mengenai jaminan fidusia dan telah disepakati oleh para pihak dalam perjanjian pembiayaan konsumen kendaraan bermotor. Perusahaan pembiayaan yang melanggar ketentuan Peraturan Menteri ini dikenakan sanksi administratif secara bertahap berupa peringatan; pembekuan kegiatan usaha; atau pencabutan izin usaha. Peraturan Menteri Keuangan ini bertujuan untuk memberikan kepastian hukum bagi para pihak, yaitu perusahaan pembiayaan konsumen dan konsumen.

Lahirnya hak kebendaan pada hak kebendaan yang bersifat memberikan jaminan, yaitu digantungkan pada penerapan dari asas publisitas, dengan mendaftarkan ke kantor pendaftaran maka lahirlah hak kebendaan, kecuali untuk lembaga gadai yang tidak ada ketentuan tentang pendaftaran dan lembaga pendaftaran maka perwujudan asas publisitas dengan cara benda gadai diserahkan ke pemegang gadai (kreditor) atau pihak ketiga. Berdasarkan pada uraian di atas maka dapat dirangkum dalam tabel sebagai berikut. 
Tabel 1

Lahirnya Hak Kebendaan Bersifat Memberikan Kenikmatan

\begin{tabular}{ccc}
\hline No & \multicolumn{1}{c}{ Macam Benda } & \multicolumn{1}{c}{ Cara Perolehan } \\
\hline $1 \quad$ Benda bergerak yang berwujud & Pasal 612 ayat $1 \mathrm{BW}$ dilakukan dengan penyerahan nyata atau \\
& penyerahan dari tangan ke tangan.
\end{tabular}

Tabel 2

Lahirnya Hak Kebendaan Bersifat Memberikan Jaminan

\begin{tabular}{|c|c|c|}
\hline No & Lembaga Jaminan & Lahirnya Hak Kebendaan \\
\hline 1 & Gadai & $\begin{array}{l}\text { Pada saat benda gadai diserahkan kekuasaannya pada pihak kreditor atau pihak ketiga. } \\
\text { Hal ini merupakan perwujudan dari asas inbezitstelling (Pasal } 1152 \text { ayat } 1 \mathrm{BW} \text { ) }\end{array}$ \\
\hline 2 & Hipotek kapal laut berbobot $20 \mathrm{~m}^{3}$ & $\begin{array}{l}\text { Dilakukan pendaftaran ke Pejabat Pendaftar dan Pencatat Balik Nama Kapal di tempat } \\
\text { kapal didaftarkan dan dicatat dalam Daftar Induk Pendaftaran Kapal (Pasal } 1179 \text { BW } \\
\text { juncto Pasal } 60 \text { Undang-Undang No. } 17 \text { Tahun } 2008 \text { tentang Pelayaran) }\end{array}$ \\
\hline 3 & Hak Tanggungan & $\begin{array}{l}\text { Lahirnya hak tanggungan berdasarkan pada Pasal } 13 \text { ayat } 5 \text { Undang-Undang Hak } \\
\text { Tanggungan, yaitu pada hari tanggal buku tanah hak tanggungan sebagaimana dimaksud } \\
\text { pada ayat } 4 \text {. Tanggal buku tanah hak tanggungan adalah hari ketujuh setelah penerimaan } \\
\text { secara lengkap surat-surat yang diperlukan bagi pendaftaran }\end{array}$ \\
\hline 4 & Fidusia & $\begin{array}{l}\text { Pasal } 14 \text { ayat } 3 \text { Undang-Undang No. } 42 \text { Tahun } 1999 \text { tentang Jaminan Fidusia bahwa } \\
\text { jaminan fidusia lahir pada tanggal sama dengan tanggal dicatatnya jaminan fidusia } \\
\text { dalam Buku Daftar Fidusia. }\end{array}$ \\
\hline
\end{tabular}

\section{PENUTUP}

\section{Kesimpulan}

Hak kebendaan (zakelijk recht) adalah hak mutlak atas suatu benda, hak itu memberikan kekuasaan langsung atas suatu benda dan dapat dipertahankan terhadap siapapun juga. Hak kebendaan lawannya adalah hak perorangan (persoonlijk recht), yang merupakan bagian dari hukum perdata. Hak kebendaan dalam BW dapat dibedakan menjadi hak kebendaan yang memberikan jaminan (zakelijk zekenheidsrecht), contoh: gadai, hipotek, hak tanggungan, fidusia dan hak kebendaan yang memberikan kenikmatan (zakelijk genotsrecht) contoh: hak milik, bezit. Hak kebendaan mempunyai ciri-ciri unggulan antara lain bersifat mutlak, asas droit de suite, asas prioritas, asas droit de preference, dan gugat kebendaan.

Bahwa lahirnya hak kebendaan yang bersifat memberikan jaminan, yaitu Hipotek, Hak Tanggungan, dan juga Fidusia digantungkan pada penerapan dari asas publisitas, yaitu dengan mendaftarkan ke kantor pendaftaran. Konsekuensi lahirnya hak kebendaan membawa akibat melekatnya ciri-ciri unggulan dari hak kebendaan. Pada lembaga jaminan gadai tidak ada ketentuan tentang kewajiban pendaftaran dan lembaga pendaftaran, sehingga perwujudan dari asas publisitas, yaitu dengan cara benda gadai diserahkan ke pemegang gadai (kreditor) atau pihak ketiga. 


\section{Rekomendasi}

Pada perusahaan pembiayaan, perusahaan yang bersangkutan hendaknya melakukan pendaftaran untuk jaminan fidusianya segera setelah lahirnya perjanjian jaminan, dimana hal itu berlaku sebagai perwujudan dari asas publisitas hak kebendaan, dan agar melekat padanya berbagai keistimewaan hak kebendaan, termasuk diantaranya yaitu memiliki kedudukan sebagai kreditor preferen.

\section{DAFTAR PUSTAKA}

\section{Buku:}

Badrulzaman, Mariam Darus, 2010, Mencari Sistem Hukum Benda Nasional, Bandung: Alumni.

Departemen Keuangan Republik Indonesia, Badan Pendidikan dan Pelatihan Keuangan, 2009, Modul Hukum Benda.

Hutagalung, Arie, 2008, "Praktek Pembebanan dan Pelaksanaan Eksekusi Hak Tanggungan di Indonesia”, Jurnal Hukum dan Pembangunan, Tahun ke-38, No. 2. Hlm. 148-315.

Hasbullah, Frieda Husni, 2005, Hukum Kebendaan Perdata Hak-Hak yang Memberi Kenikmatan, Jilid I, Jakarta: Ind-Hill-Co.

Isnaeni, Moch., 1996, Hipotek Pesawat Udara di Indonesia, Surabaya: Dharma Muda.

Prawirohamidjojo, R. Soetojo dan Marthalena Pohan, 1984, Bab-Bab tentang Hukum Benda, Surabaya: Bina Ilmu.

Law Librarian's Notes, Hipotek, Pendaftaran dan Kebangsaan Kapal, http://www.blog.detik, diunduh pada Sabtu, 18 Agustus 2012, jam 15.51 WIB.

R. Subekti, R. Tjitrosudibio, 2006, Kitab UndangUndang Hukum Perdata, terjemahan dari Bugerlijk Wetboek, Jakarta: Prandya Paramita.
Sofwan, Sri Soedewi Masjchoen, 1981, Hukum Benda, Yogyakarta: Liberty.

Tumbuan, Fred B.G., 2012, "Mencermati Pokok-pokok Undang-Undang Fidusia”, Buletin Hukum Perbankan dan Kebanksentralan Volume 10, Nomor 2. Hlm. 1-86.

Usman, Rachamadi, 2011, Hukum Kebendaan, Jakarta: Sinar Grafika.

Usanti, Trisadini P., et.al., 2012, Buku Ajar Hukum Perdata, Surabaya: FH Universitas Airlangga.

Yahman, dan Trisadini Prasastinah Usanti, 2011, Bunga Rampai Hukum Aktual dalam Perspektif Hukum Bisnis Kontraktual Berimpikasi Pidana dan Perdata, Surabaya: Mitra Mandiri.

\section{Peraturan Perundang-Undangan:}

Undang-Undang No. 4 Tahun 1996 tentang Hak Tanggungan atas Tanah beserta Benda-Benda yang Berkaitan dengan Tanah. Lembaran Negara Republik Indonesia Tahun 1996 No. 42.

Undang-Undang No. 42 Tahun 1999 tentang Jaminan Fidusia. Lembaran Negara Republik Indonesia Tahun 1999 No. 168.

Undang-Undang No. 17 Tahun 2008 tentang Pelayaran. Lembaran Negara Republik Indonesia Tahun 2008 No. 64.

Peraturan Menteri Keuangan Republik Indonesia No: 130/PMK.010/2012 tentang Pendaftaran Jaminan Fidusia bagi Perusahaan Pembiayaan yang Melakukan Pembiayaan Konsumen untuk Kendaraan Bermotor dengan Pembebanan Jaminan Fidusia. Berita Negara Republik Indonesia Tahun 2012 No. 786. 